Ritrýnd grein birt 27. ágúst 2018

\title{
Ævintýralegt jafnrétti. Starfendarannsókn í leikskóla
}

\author{
Anna Elísa Hreiðarsdóttir
}

\section{Abstract $\quad$ Um höfund $\quad$ About the author $>$ Heimildir}

Grein pessi fjallar um starfendarannsókn sem gerð var á deild fjögurra ára barna í leikskólanum Iðavelli, Akureyri, veturinn 2013-2014. Pá vann skólinn að próunarverkefninu Ævintýralegt jafnrétti með styrk frá Sprotasjóði mennta- og menningamálaráðuneytisins og var höfundur greinarinnar verkefnisstjóri. Próunarverkefnið bar heitið Ævintýralegt jafnrétti. Kynjahugmyndir leikskólabarna og miðaði að pví að vinna markvisst með börnum að fjölbreyttum verkefnum tengdum kynhlutverkum og jafnrétti.

Markmið starfendarannsóknarinnar var að efla kennara sem fagmenn og auka færni peirra til að próa eigin starfshætti með pví að fylgjast kerfisbundið með og endurskoða vinnuna við próunarverkefnið, ekki síst pátttöku og framlag barnanna. Dátttakendur voru kennarar á deild fjögurra ára barna og börnin á deildinni. Gagnaöflun fór fram með skráningu á fundum og viðtölum við kennara og börnin sjálf, sem og við samanburðarhóp barna. Um skráningar sáu kennarar og verkefnisstjórar með ljósmyndum og upptökum, og gögnum um verkefni barnanna var safnað markvisst.

Niðurstöður sýna að kennarar urðu meðvitaðir bæði um eigin hugmyndir tengdar jafnrétti sem og viðfangsefni sem vinna má að með börnunum og pað kom skýrt fram að frumkvæði kennara skipti miklu máli. Einnig má ráða af niðurstöðum að hæfni barna til gagnrýninnar umræðu jókst eftir pví sem verkefninu fleytti fram en hún dalaði einnig hratt ef henni var ekki haldið við. Hluti af vinnu við verkefnið fólst í að vinna kennsluefni sem leikskólar geta nýtt sér. Kennsluefnið er í premur hlutum. Einn peirra er fyrir kennara, annar fyrir vinnu með foreldrum og loks eru verkefni til að vinna með börnum. Skýrslu um framgang próunarverkefnisins var skilað til Sprotasjóðs og kennsluefnið er aðgengilegt á vef (Anna Elísa Hreiðarsdóttir, 2014; idavollur.is).

Efnisorð: Leikskóli, kynjajafnrétti, ævintýri, kyngervismótun, starfendarannsókn. 


\section{Inngangur}

Á undanförnum árum hefur kynjajafnrétti á Íslandi mælst hið mesta í heiminum pegar miðað er við heilsu, menntun, efnahag og stjórnsýslu (Hausmann, Tyson, Bekhouche og Zahidi, 2014). Dó fréttir af pessu tagi séu gleđiefni pýða pær ekki að jafnrétti hafi náđst. Í pví sambandi má nefna að árið 2014 var landið annað tveggja í heiminum til að ná að brúa meira en $60 \%$ af peim mismun sem er milli kynja (e. gender gap) og tengist heilsu, menntun, efnahag og stjórnmálum. Eftir stendur tæplega 40\% bil sem sýnir að eitt og annað er óunnið á pessum vettvangi. Nýlegar rannsóknir hafa einnig sýnt ákveðið bakslag í jafnréttismálum, til dæmis ef tekið er mið af viðhorfum unglinga til kynhlutverka (Andrea Hjálmsdóttir og Dóroddur Bjarnason, 2008a og b), sem hlýtur að teljast áhyggjuefni. Fleiri neikvæð dæmi má nefna, svo sem að launamunur karla og kvenna jókst á milli áranna 2014 og 2015, og svo virðist sem konur hafi minni væntingar til launa sinna en karlar (Verzlunarmannafélag Reykjavíkur, 2015). Möguleikar og takmarkanir tengdar kyni virðast hafa áhrif á bæði kynin (Dorbjörg Helga Vigfúsdóttir o.fl., 2011), til dæmis á afstöðu drengja til náms, bæði til háskólanáms almennt en sérstaklega pó til náms til hefðbundinna kvennastarfa eins og hjúkrunar og kennslu. Félagslegur brýstingur virðist vera meiri á karla en konur pegar kemur að starfsvali og ávinningur peirra af pví að velja störf sem samfélagið telur kvennastörf er minni en kvenna sem velja hefðbundin karlastörf. Deir karlar sem velja slík störf eiga pað á hættu að aðrir karlar taka pá síður alvarlega (Kauppinen-Toropainen og Lammi 1993; King 1998; Williams og Villemez, 1993).

Frá árinu 2000 hefur skólum verið ætlað pað hlutverk að veita fræðslu um jafnréttismál (lög um jafna stöðu og jafnan rétt kvenna og karla nr. 96/2000) og í lögum um leik- og grunnskóla kemur fram að starfshættir skóla skuli einkennast af jafnrétti (lög um leikskóla nr. 2008/90; lög um grunnskóla nr. 2008/91). Íslensk menntastefna leggur áherslu á sex grunnpætti menntunar og er einn grunnpátturinn jafnrétti. Markmið skólastarfs eru tengd tiltekinni hæfni sem felst í pekkingu, leikni og viðhorfum (Aðalnámskrá leikskóla, 2011). Pað er pví skylda hvers skóla að stuðla að jafnrétti, vinna með jafnrétti og efla jafnréttishugsun barna og kennara. Á hinn bóginn hefur verið bent á að tiltakanlegur skortur sé á jafnréttisfræðslu í skólum (t.d. Eygló Árnadóttir, 2009; Dorgerður Einarsdóttir og Ingólfur Ásgeir Jóhannesson, 2011) og Ingólfur Ásgeir Jóhannesson (2011) segir að til að ná árangri purfi skólar að gera fræðslu um kynjajafnrétti samfellda og markvissa. İ aðalnámskrám leik- og grunnskóla kemur fram að markviss jafnréttisfræðsla sé mikilvæg, m.a. gefi hún börnum færi á að skilja betur samfélagið sem pau lifa í og geri pau færari til pátttöku og áhrifa. Lögð er áhersla á mikilvægi pess að börnum gefist tækifæri til að takast á við umræðu og verkefni um jafnrétti (Aðalnámskrá leikskóla, 2011). Jafnréttismenntun felur meðal annars í sér gagnrýna skoðun á viðteknum hugmyndum í samfélaginu og pað, ásamt tiltrú á mikilvægi pess að vinna að markvissri jafnréttis- og kynjafræðslu frá unga aldri, er viðfangsefni rannsóknarinnar sem hér er til umfjöllunar. Starfendarannsóknin fylgdi eftir próunarverkefni um jafnrétti sem unnið var í leikskólanum Iðavelli á Akureyri veturinn 2013-2014. Dróunarverkefnið hlaut styrk úr Sprotasjóði mennta- og menningamálaráðuneytisins og hluti af ferlinu var að skila skýrslu um framganginn til sjóðsins (sjá á sprotasjodur.is). Samhliða var samið og kennt í tilraunarskyni kennsluefni í jafnréttisfræðslu fyrir leikskóla og er pað aðgengilegt á heimasíðu leikskólans (idavolllur.is).

Markmið rannsóknarinnar var að gera vinnuna við próunarverkefnið markvissari og efla kennara 1 a a skoða eigin starfshætti með áherslu á kynjajafnrétti og kynhlutverk í starfinu með börnunum. Af pví leiðir að markmið rannsóknarinnar fléttast að hluta til saman við markmið próunarverkefnisins, en pau voru eftirfarandi:

- Að vinna með og efla jafnréttisvitund leikskólabarna.

- Að efla vitneskju kennara um leiðir og árangur af markvissri jafnréttis- og kynjafræðiumræð.

- Að leita árangursríkra leiða til að vinna með jafnrétti og kynjafræði í leikskóla. 
Viðfangsefni verkefnisins sneru að jafnrétti, ævintýrum, skapandi starfi, leik og valdeflingu barna og áhersla var lögð á að leiðirnar væru útfærðar í gegnum sampætt skólastarf. Verkefnið fólst annars vegar í að vinna markvisst með valin ævintýri til að stuðla að aukinni vitund barna og kennara um jafnrétti og kynhlutverk, möguleika og takmarkanir. Hins vegar var ætlunin að nýta ferlið, og vinnu barna og hugmyndir peirra, til að útbúa námsefni fyrir leikskóla um jafnréttis- og kynjahugmyndir barna og hvernig megi vinna með pær í gegnum sögur og leik. Sem leið að markmiðum var börnunum skapað tækifæri til að taka virkan pátt í umræðu um jafnrétti og kynjafræði á eigin forsendum, par sem peim var skapað svigrúm til að takast á við viðteknar hugmyndir um kynhlutverk og gefið færi á að greina og vinna með möguleika og takmarkanir í hugmyndum um kynhlutverk. Unnið var að pví að efla gagnrýna hugsun barnanna með sögugerð og leik og umhverfið gert hvetjandi til sögugerðar og skapandi vinnu með jafnréttis- og kynjasjónarmið að leiðarljósi.

Áætlunin gerði ráð fyrir að unnið yrði með ævintýri sem voru valin vegna pess að pau eru vel pekkt og líklegt að allflest börnin hefðu heyrt pau áður en verkefnið hófst. Ævintýrin voru talin hafa ákveðna eiginleika sem póttu falla vel að verkefninu, t.d. er ekkert peirra með prinsessuívafi né heldur lýkur sögunum með giftingu, en hvoru tveggja eru atriði sem huga parf að í tengslum við kynhlutverk. Pá greina pau öll frá sögupersónum af báðum kynjum sem sýna bæði umhyggju og hugrekki. Fyrsta ævintýrið var um stúlkuna Rauðhettu, en síðan var unnið með Búkollu, par sem drengur er í aðalhlutverki. Að síðustu var ætlunin að fjalla um systkinin Hans og Grétu en áhugi barnanna leiddi verkefnið frá peirri sögu. Ævintýrunum var ætlað að vera grunnur að umræðu og börnin köfuðu saman, undir handleiðslu kennara, ofan í hugmyndir um stúlkur og drengi, pað sem peim er ætlað og pað sem pau geta. Fyrst voru hugmyndir barnanna við upphaf verkefnisins til skoðunar en síðan var unnið með pær með umræðu í barnahópnum. Markvisst var unnið með sögugerð og börnunum sköpuð mýmörg tækifæri til að útfæra hugmyndir sínar í eigin ævintýrum og próa pær í hlutverkaleik úti og inni.

\section{Mótun kyngervis}

Árið 1987 kom út grein sem olli nokkrum tímamótum í umræðu um kynjafræði (West og Zimmermans, 1987) en par var dreginn fram munur á kyni (e. sex) annars vegar og kyngervi (e. gender) hins vegar. West og Zimmermans sögðu kyngervið mótað af samfélaginu í takt við pað sem teldist eðlilegt og viðeigandi fyrir kyn einstaklingsins. Detta ferli kölluðu pau mótun kyngervis (e. doing gender, síðar einnig kallað gendering). Mótun kyngervis getur átt rætur sínar í eðlishyggju, p.e. peirri trú að pað sé eðlislægur munur á körlum og konum, eða tvíhyggju sem vísar til pess að kynin hafi andstæða eiginleika. Flokkanir af pessum toga leiða af sér staðalmyndir (e. stereotypes), m.a. um eiginleika og getu, par með talin pau viðfangsefni og störf sem hæfa hvoru kyninu fyrir sig (Berglind Rós Magnúsdóttir, Guðrún M. Guðmundsdóttir, Jóna Pálsdóttir, Kristín Ástgeirsdóttir og Kristín Jónsdóttir, 2010). Montgomery (2009) færir rök fyrir pví að kynhlutverk séu ólík eftir samfélögum og pví megi draga pá ályktun að pau séu afurð samfélagsins en ekki líffræðilegra pátta, og Spade og Valentine (2008) taka undir pað og segja að ekki finnist, pegar horft er til jarðarinnar allrar, einn sannleikur um skilgreiningar á kynhlutverkum, hvorki tengdur væntingum né ábyrgð.

Lise Eliot (2009) segir að margt í hugmyndum um mótun kyngervis sé hamlandi og jafnvel skaðlegt til lengri tíma litið fyrir bæði kynin. Í rannsóknum sínum hefur hún kafað ofan í niðurstöður og aðferðir við heilarannsóknir, sérstaklega pær sem stutt hafa tvíhyggju og eðlishyggju. Eliot segir undravert hve lítil sönnunargögn liggi að baki fullyrðingum um mun á börnum eftir kyni. Hún segir greinanlegan mun tvenns konar. Annars vegar sé heili drengja að meðaltali stærri en stúlkna við fæðingu en pað sé í réttu hlutfalli við mun á fæðingarpyngd eftir kyni. Hins vegar hætti heili stúlkna að proskast að meðaltali tveimur árum fyrr en heili drengja, aftur nátengt öðrum líkamlegum proska. Eliot (2009) færir rök fyrir pví að pó hugsanlega megi tengja stærri heila við meiri líkamlega virkni drengja og hæfni varðandi rýmisgreind eða verkfræði útskýri 
minni heili ekki meiri málfærni stúlkna né samskiptahæfni, svo nefnd séu pau atriði sem helst eru dregin fram pegar fjallað er um mismunandi námsgetu drengja og stúlkna. Lucas-Stannard (2012) hafnar bví einnig að kynjamunur sé svo mikill sem af er látið og telur, eins og Eliot (2009), að muninn megi að mestu rekja til pess að frá fæðingu séu börn alin upp ólíkt eftir kyni. Báðar telja pær að eiginleikar og áhugi ætti fremur að vera ráđandi í uppeldi og að börn ættu að fá tækifæri til að verða pað sem pau vilja eða geta orðið, án pess að kynið verði pröskuldar á vegi peirra.

Margir pættir hafa áhrifá mótun kyngervis, svo sem ríkjandi orðræða (Deutsch, 2007), væntingar og viðbrögð (Eliot, 2009), en ekki síður viðfangsefni barna og afpreyingarefni (Jackson, 2007; Jones og Dindia, 2004; Dórdís Dórðardóttir, 2012; Änggård, 2005). Allt eru petta samfélagslegir og menningartengdir pættir en ekki líffræðilegir. Davies (2003) telur að með pví að kynnast fjölmörgum litbrigðum samfélagsins geti einstaklingar staðsett sig víða og með margvíslegum hætti, bæði í samræmi við pað hvernig aðrir vilja flokka pá en einnig pvert á pað sem ætlast er til af peim. Dað sé hins vegar erfitt fyrir einstakling að fara aðrar leiðir en samfélagið gerir rád fyrir. Í doktorsrannsókn Guðrúnar Öldu Harðardóttur (2014) var ein niðurstaðan einmitt sú að kennarar styddu ríkjandi hugmyndir um kynhlutverk og pað hefti möguleika barnanna og valdeflingu peirra. Rannsóknir síðustu ára hafa leitt í ljós að ung börn öðlast snemma vitneskju um kyngervi og pað hvernig kyngervin mótast (Blaise, 2005; Patterson og Bigler, 2006). Rannsóknir hafa sýnt að jafnvel pó að börn taki dæmi úr eigin lífi sem eru frávik frá staðalmyndunum gefi pau gjarnan um leið útskýringar á borð við pær að petta sé ekki venjulegt (Jackson, 2007). Detta eru sömu viðbrögð og fullorðnir sýna (Ridgeway og Correll, 2004). Börn átta sig snemma á pví að pau eru annaðhvort drengir eða stúlkur, og Änggård (2005) segir börn vera afurð kynjaðrar bernsku og að foreldrar móti börn sín í kynhlutverk, sérstaklega drengi (Fine, 2010). Vísbendingar eru um að drengir samsami sig tilætluðum kynhlutverkum fyrr en stúlkur, jafnvel svo ungir sem 25 mánaða gamlir (Bauer, 1993). Davies (2003) áréttar að börn séu pátttakendur í eigin mótun og einkennum en pau upplifi samfélag par sem gerður sé skýr greinarmunur á konum og körlum, drengjum og stúlkum, og pau dragi pá ályktun að pau verði að velja viðeigandi kynhegðun; falla í mótið.

Kyngervismótun hefur áhrif á fjölmarga pætti í lífi barna, par á meðal á leik peirra. Frost, Wortham og Refiel (2008) segja að bæði drengir og stúlkur kjósi að leika við börn af sama kyni og að rannsóknir sýni að margpættan mun megi finna á leik drengja og stúlkna. Hins vegar svari rannsóknir pví ekki hve stóran hlut samfélagslegir pættir eigi í pessum mun á leik drengja og stúlkna á leikskólaaldri. Paechter (2007) segir mótun kyngervis hafa áhrif á viðfangsefni og leik barna frá unga aldri og Davies (2003) er á sama máli og telur barnabækur styðja staðalmyndirnar og efla pannig hugmyndir barna um pað hvað hæfi peim að fást við og gera eftir pví af hvoru kyninu pau eru. Bent hefur verið á að vinsælt barnaefni, svo sem frá Disney og Pixar, getur gefið börnum mótandi hugmyndir pví drengir fá par aðalhlutverkin, framkvæma og slást en stúlkur bíða og eru fallegar og snyrta sig (Maríanna Clara Lútersdóttir, 2012). Börn yfirfæra reynslu sína af barnaefni í leik og drengir taka meira rými í leik en stúlkur (Paechter, 2007). Almennt er drengjamenning talin virðingarverðari en stúlknamenning (Dórdís Dórðardóttir, 2012) og virðing virðist pví vera tengd kyngervinu og par með vera áhrifapáttur í stöðu barna í félagahópnum (Pórdís Pórðardóttir, 2015). Leikur barna er einnig leið til að æfa og móta kyngervi (Blaise, 2005) og við sögugerð velja börn fremur pemu, stíl og viðfangsefni í takt við kyn sitt og drengir veigra sér við að teikna stúlkur, hvort heldur er raunverulegar eða ævintýrapersónur (Änggård, 2005). Af framansögðu má ráđa að kyngervismótunin hafi áhrif á börn af báðum kynjum, drengi ekki síður en stúlkur.

Butler (2004) segir að kyngervið sé kvikt og pví sé hægt að vinna með pað og breyta pví og margir rannsakendur leggja áherslu á mikilvægi pess að brjóta upp staðalmyndir (e. undoing gender) (m.a. Butler, 2004; Deutsch, 2007). Tilgangurinn er pá að minnka pann óhagstæða mun sem búinn er til með mótun kyngervis. Kennarar og skólar gegna mikilvægu hlutverki hvað petta varðar. Fine (2010) leggur áherslu á að til að geta staðið undir pessu hlutverki sínu purfi kennarar að hafi nýjustu pekkingu með í farteskinu og pað sé mikilvægt að peir séu gagnrýnir 
á rannsóknir, ekki síst rannsóknir tengdar kyngervinu. Katrín Friðriksdóttir og Sigrún Aðalbjarnardóttir (2002) benda á pað að kennarar purfi einnig að huga að viðhorfum sínum pví pau geti haft áhrif á athafnir peirra, m.ö.o. geti umhverfið í skólum og framkoma kennara valdið eða viðhaldið bjögun (e. bias) í viðhorfum barna (Patterson og Bigler, 2006). Peachter (2007) heldur pví fram að mismunun eftir kyni viðhaldist og próist innan skóla og Patterson og Bigler (2006) segja að kennsluaðferðir geti haft mælanleg áhrif á viðhorf barna til flokkunar fólks í hópa. Í viðamikilli yfirlitsrannsókn á samskiptum kennara við nemendur út frá kynjasjónarmiðum kom í ljós að kennarar mættu stelpum og strákum á ólíkan hátt, alveg sama af hvoru kyni kennarinn var, og margt í skólaumhverfinu byggðist á eðlis- og tvíhyggju (Jones og Dindia, 2004). Blaise og Taylor (2012) segja mikilvægt að kennarar skilji að ef börn fá ekki tækifæri til að ígrunda staðalmyndirnar sé líklegt að pau reyni að samsama sig pví sem pau telja rétt, til að forðast bæði höfnun og stríðni. Hins vegar komst Fine (2010) að peirri niðurstöðu að kennarar telji pað ekki fyrirhafnarinnar virði að vinna með staðalmyndir, takmarkanir og möguleika.

Önnur hlið á kyngervismótun innan skóla er fyrirmyndirnar og fordæmin sem börnunum eru gefin. Pruit (2015) segir kynjaða verkaskiptingu tíðkast innan leikskólans og hún geti viðhaldið hugmyndum barna um staðalímyndir og hefðbundin kynhlutverk. Íslenskar rannsóknir hafa sýnt sömu niðurstöðu, bæði að verkaskipting í leikskólum sé kynjuð og að hefðbundinni sýn á kynhlutverk sé viðhaldið (Anna Elísa Hreiðarsdóttir, 2006; Laufey Axelsdóttir og Gyða Margrét Pétursdóttir, 2014). Í niðurstöðum rannsóknar Guðrúnar Öldu Harðardóttur og Gyðu Margrétar Pétursdóttur (2014) kom fram að kyn er áhrifapáttur í leikskóla; kennarar hafa tilhneigingu til að flokka börn eftir kyni. Dær stöllur draga pá ályktun að kennarar trúi pví að pað sé náttúrulegur munur á börnum eftir kyni og líkur séu á að pað viðhaldi staðalmyndum af kynhlutverkum. Eðlishyggja virðist einnig einkenna orðræðuna (Laufey Axelsdóttir og Gyða Margrét Pétursdóttir, 2014), en leikskólakennarar purfa að vera meðvitaðir um pað hvernig mótun kyngervis á sér stað til að geta unnið með hana (Guðrún Alda Harðardóttir og Gyða Margrét Pétursdóttir, 2014). Dórdís Dórðardóttir (2012) telur leikskólakennara hins vegar lítið hirða um að takast á við staðalmyndir, og tilfinnanlegur skortur virðist vera á jafnréttispekkingu í leikskólum (Laufey Axelsdóttir og Gyða Margrét Pétursdóttir, 2014). Jafnrétti og jöfnuður er ofarlega á baugi í samfélagslegri umræðu víða um heim um pessar mundir og hvoru tveggja eru mikilvægir pættir í menntun. Sömu áherslur má greina hér á landi, eins og sjá má í lögum, aðalnámskrá, pemahefti um jafnrétti, stefnum sveitarfélaga og áherslu á einstaklingsmiðun í námi, en til pess að ná jafnrétti parf, eins og Browne (2004) segir, að viðurkenna og greina pau öfl sem eru að verki í umhverfi barna. Dannig megi finna leiðir til breytinga.

Starfendarannsóknin sem hér er fjallað um fólst í pví að fylgja eftir vinnu við próunarverkefni um jafnrétti í leikskólastarfi á deild fjögurra ára barna í leikskóla. Verkefnið fór fram veturinn 2013-2014 og tóku allir fjórir kennarar á deildinni pátt í pví, og öll börnin, 24 talsins. Hlutverk kennara fólst í pví að reyna nýjar aðferðir, tilraunakenna kennsluefni og prófa mismunandi aðferðir við mat.

Rannsóknarspurningar voru eftirfarandi:

- Hvernig geta kennarar próað leiðir til markvissrar jafnréttis- og kynjaumræðu leikskólabarna?

- Hvernig má vinna með ævintýri sem lið í jafnréttiskennslu?

- Hvernig má efla pátttöku og framlag barna? 


\section{Aðferð}

Rannsóknaraðferðin er starfendarannsókn (e. action research) en sérstaða aðferðarinnar felst í pví að byggt er á fagbekkingu kennara á vettvangi (Jóhanna Einarsdóttir, 2009) og að um er að ræða ferli sem hentar vel til að halda utan um próunarstarf. Í rannsókninni skoðuðu kennarar jafnt og pétt eigið framlag með pað að markmiði að bæta starfsaðferðir sínar, finna nýjar aðferðir og gera tilraunir (McNiff, 2013). Unnið var með hugmyndir að nýju kennsluefni sem mótaðist í gegnum kennsluaðferðir og reynslu en einnig viðbrögð barna og hugmyndir peirra. Aðferðafræði verkefnisins var hugsuð út frá námskrá og aðferðum skólans par sem verkefnið fór fram en par réði för lýðræðisleg umræða, samvinna kennara og barna á jafningjagrunni, sjálfstæð hugsun og skapandi starf. Detta pýðir meðal annars að börnin réðu sjálf hvort pau tóku pátt í einstökum hlutum verkefnis og oft höfðu pau frumkvæði að vinnustundum eða fundum, sérstaklega eftir pví sem á veturinn leið. Winswold og Solberg (2010) segja að einn páttur í lýðræðislegri vinnu skóla felist í pví að pjálfa með börnum lýðræðisleg vinnubrögð, meðal annars með umræðum, eins og gert var í verkefninu. Val á vinnubrögðum var einnig í takt við ákvæði barnasáttmálans (lög um samning Sameinuðu pjóðanna um réttindi barnsins nr. 19/2013) um réttindi barna til að á pau sé hlustað og Aðalnámskrá leikskóla (2011) um að börn séu pátttakendur í ákvörðunum og umræðum.

Í rannsóknum með pátttöku ungra barna er einkar mikilvægt að virða sampykki peirra og vilja til pátttöku (Dockett, Jóhanna Einarsdóttir og Perry, 2012) og í ferlinu var sérstaklega leitast við аð virða pessa pætti, meðal annars með pví að hafa pátttöku barnanna valfrjálsa en einnig gættu rannsakendur pess að bjóða börnunum, og aðstoða pau við, að hætta pátttöku, sérstaklega í rýniviðtölunum.

\section{Gagnaöflun og úrvinnsla gagna}

Gagnaöflun beindist að pví að fylgjast með starfspróun kennara, ígrundun og vinnubrögðum meðan á starfendarannsókninni stóð. Á sama tíma var rýnt í hugmyndir barnanna og vinnubrögð með áherslu á framfarir. Starfspróun kennara fólst í að rýna í og meta eigið starf, taka sérstaklega eftir tækifærum til að vinna með jafnrétti í daglegu starfi skólans, meðal annars með pví að lesa í ólíkan tjáningarmáta barnanna og gefa peim fjölbreytt tækifæri til að tjá sig með skapandi hætti og hafa rökstuddar skoðanir.

Vorið áður en verkefnið hófst af fullum krafti hélt verkefnisstjóri hálfs dags námskeið og vinnusmiðjur fyrir alla kennara skólans um kynjajafnrétti par sem peir unnu með eigin hugmyndir og vinnubrögð. Annan dagpart var vinnusmiðja um málörvun með áherslu á að vinna með sögur og ævintýri í gegnum leik og skapandi starf. Haft var samband við foreldra til að afla nauðsynlegra leyfa og peir upplýstir um rannsóknina. Tekin voru rýnihópaviðtöl við barnahópinn sem var í leikskólanum meðan á undirbúningi verkefnisins stóð og sýn peirra barna hafði áhrif á upphaf verkefnisins. Í lok verkefnisins voru tekin sambærileg rýniviðtöl við börnin sem tóku pátt í verkefninu en einnig var lagt mat á stöðu peirra við upphaf og við lok verkefnisins með áherslu á að kanna jafnréttisvitund peirra.

Verkefnið hófst formlega í september með kynningu fyrir foreldra og starfsmenn á deildinni. Fundað var með foreldrum en einnig var stofnaður opinn fésbókarhópur (Jafnrétti í uppeldi og menntun leikskólabarna) um verkefnið fyrir kennara og foreldra. Haldinn var fundur með starfsmönnum og fyrstu fundir með börnunum. Á nýju ári var haldið málping fyrir foreldra og kennara um jafnréttisuppeldi. Könnun var lögð fyrir foreldra í upphafi og í lok verkefnisins og svöruðu foreldrar bæði lokuðum spurningum og hálfopnum. Spurt var um viðhorf peirra til verkefnisins annars vegar og mat peirra á framkvæmd og árangri hins vegar. Lokaðar spurningar voru notaðar til að meta pörf á fræðslu, viðbrögðum og kynningu en hálfopnar spurningar voru pemagreindar til að kortleggja viðhorf foreldra til verkefnisins. Í fyrri foreldrakönnuninni kom fram að allir foreldrar vildu leyfa opinbera notkun á ljósmyndum, upptökum og efni barna en 
10 vildu að nöfn barnanna kæmu ekki fram. Pví er nöfnum barna eytt úr gögnunum. Kannanir voru einnig lagðar fyrir alla kennara skólans.

Uppeldisfræðileg skráning (e. pedagogical documentation) var notuð til gagnaöflunar par sem hún hentar vel til að fá innsýn í nám barna og hvernig pau skapa merkingu í gegnum fjölbreytt viðfangsefni (Palaiologou, 2016). Kennarar og verkefnisstjóri héldu dagbækur og tóku vettvangsnótur jafnt og pétt allan veturinn og voru pær notaðar til að ígrunda ferli, árangur og stöðu. Reglulega voru gerðar myndbandsupptökur, bæði af leik barnanna og skipulögðum stundum. Kennarar og verkefnisstjóri unnu úr gögnum og voru myndbandsupptökur greindar með áherslu á rannsóknarspurningar um breytingar eða framfarir hjá börnunum og vinnubrögð kennara. Allir fjórir kennararnir á deildinni komu að verkefninu og tóku peir að sér ákveðna verkpætti par sem einn hélt utan um skapandi starf og annar sögugerð, svo dæmi séu tekin. Allir sem á deildinni unnu komu pannig að verkefninu að meira eða minna leyti. Fundað var jafnt og pétt með kennurum yfir veturinn. Deir lásu einnig fræðsluefni og greinar um rannsóknir og svo voru útbúin kennslugögn og verkefni auk pess að meta stöðuna í barnahópnum. Nokkrum sinnum yfir veturinn voru fréttabréf sett upp í skólanum, bæði fyrir kennara á öðrum deildum og fyrir foreldra.

Í niðurstöðum og umræðum er rætt um börnin sem hóp en rétt að árétta að sum börnin sýndu meiri árangur og framfarir í einstökum páttum verkefnisins en önnur. Áhugasvið og proski barnanna skiptir par máli en ekki síður að pátttaka barnanna í verkefninu var oft valfrjáls og pví mismunandi hve lengi einstaklingar dvöldu við tiltekna pætti. Allir pættir verkefnisins voru unnir í náinni samvinnu kennara og verkefnisstjóra.

\section{Niðurstöður}

Viðamesti pátturinn í niðurstöðunum snýst um próunarverkefnið og starfið með börnunum. Sá kafli er settur fram í tvennu lagi. Annars vegar er kafli um ævintýrin og áhrif peirra á skapandi starf, sögugerð og leik. Hins vegar er fjallað um fundi barnanna par sem fóru fram umræður og kennsluefnið var forprófað. Pá eru niðurstöður rannsóknarinnar settar fram í samræmi við markmið hennar, með kafla bæði um börnin og kennara, en einnig er kafli um upplifun og viðhorf foreldra til verkefnisins. Í lokin eru dregnar saman niðurstöður af vettvangsnótum, ljósmyndum og skráningum, viðtölum við börn og kennara og rýni í verkefni barnanna, og pær settar í samhengi við rannsóknarspurningar og markmið verkefnisins.

\section{Ævintýrin}

Verkefnið hófst á haustmánuðum á pví að sagan um Rauðhettu var sett inn í leikumhverfi barnanna, bæði úti og inni. Sagan var lesin ítrekað í fjölbreyttu samhengi með ítarlegri umræðu og skoðun á hugtökum til að gefa börnunum góðan skilning á öllum páttum í sögunni. Jafnframt var sagan færð inn í skólastarfið með fjölbreyttum hætti. Fyrst var efnið kynnt fyrir börnunum en síðan var pað í boði fyrir pau í leiktímum. Börnin höfðu aðgang að sögunni á hljóðdiskum og gátu valið að hlusta pegar pau vildu. Sungið var um Rauðhettu og sagan var færð inn í leik barnanna með búningum, leikföngum og eftir fleiri leiðum (sjá Mynd 1), fyrst hin hefðbundna saga, en síðan útfærslur barnanna. Börnin fengu tækifæri til að leika persónurnar, bæði með fígúrum og búningum, endursegja sögurnar og endurskapa pær í teikningu og öðru skapandi starfi. Börnin sömdu eigin sögur og ævintýri og bjuggu til nýjar útgáfur af gömlum ævintýrum. Umræður voru útfærðar í skapandi starfi og leik. Sögurnar úti vöktu sérstaka athygli, bæði barnanna á deildinni en ekki síður annarra barna, og dæmi voru um að börnin segðu öðrum börnum sögur eða útskýrðu myndir eins og sjá má á Mynd 2. 


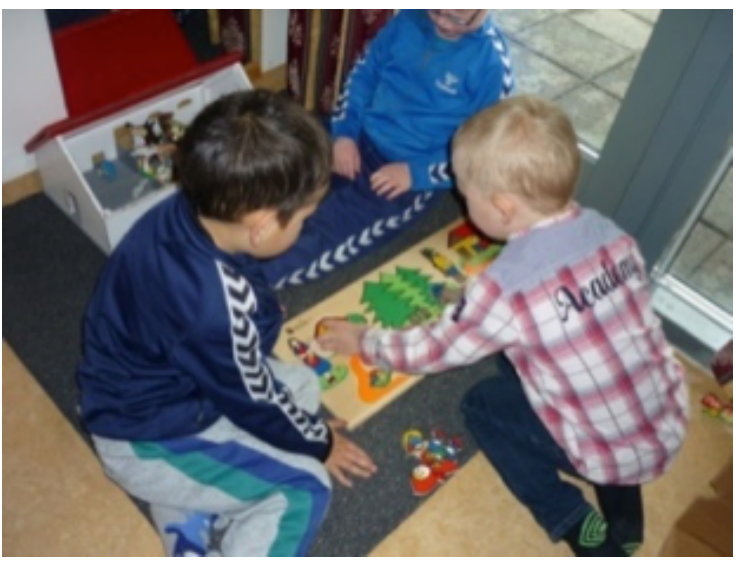

Mynd 1. Ævintýri í leik barna inni við

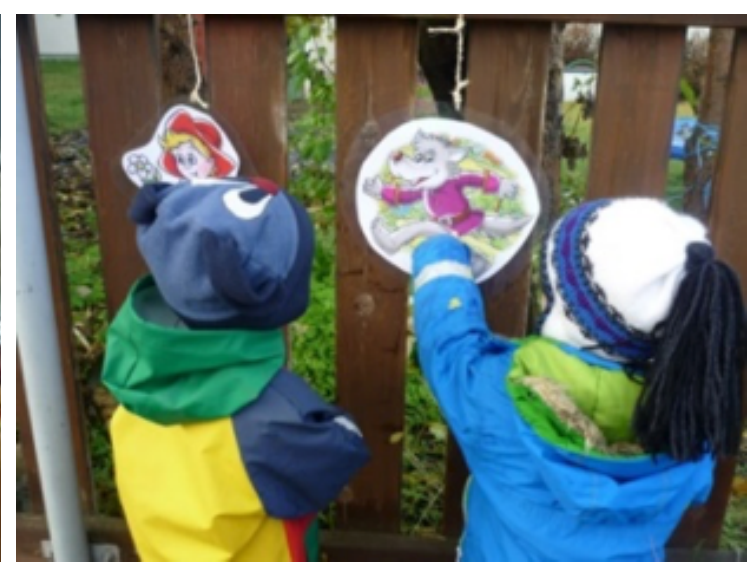

Mynd 2. Evintýri aðgengileg úti við

Fyrsta áskorunin sem kennarar mættu var að pekking barnanna á sögunni um Rauðhettu var mun minni en gert var rád fyrir og fannst kennurunum erfitt að vekja áhuga barnanna. Deir brugðu á pað ráð að setja söguna á svið, léku sjálfir öll hlutverk og sneru peim á hvolf pannig að karl lék Rauðhettu og amman varð afi á meðan bæði úlfur og veiðimaður voru leiknir af konum. Framtak peirra varð vendipunktur í vinnunni og veitti hugmyndum barnanna byr undir báða vængi, og pegar kennararnir buðu upp á rauðar húfur og refaskott í útileik barnanna fór af stað mikill og endurtekinn leikur úti par sem börnin fóru í fyrsta sinn á milli hlutverka. Tiltækið kveikti bæði umræðu og áhuga og í kjölfarið mátti sjá drengi leika Rauðhettu og stúlkur úlfa en pað höfðu börnin ekki viljað áður. Einnig hættu börnin að skilgreina úlfa sem karlpersónur og gerðu greinarmun á kyni úlfs eftir öðrum leiðum, svo sem rödd hans, eins og sjá má á samtali kennara við tvö börn:

Barn 1: Dú varst strákur í leikritinu.

Kennari:Var ég strákur?

Barn 1: Já, pú varst úlfur. Úlfar eru strákar.

Kennari: En úlfamömmur?

Barn 1:Já.

Kennari: Hvernig veit maður hvort úlfur er strákur eða stelpa?

Barn 2: Strákurinn segir HÆ [með djúpri, hrjúfri röddu] en stelpan segir HÆ [hátóna og mjúkt].

Önnur áskorunin var að pó Búkolla væri saga sem börnin pekktu mun betur pá leiddi vinnan með söguna áhuga peirra að tröllum. Ákveðið var að fylgja peim præði eftir og pví voru tröll viðfangsefnið fram undir jól, pegar jólasveinar tóku hug barnanna allan, enda tiltekinn tröllahópur par á ferð. Рað olli pví að sagan um Hans og Grétu var lögð til hliðar og kom aldrei til úrvinnslu. Áhugi barnanna hafði pví áhrif á verkefnið og breytti viðfangsefnum en kennarar sýndu bæði sveigjanleika við að víkja frá áætlun og frumkvæði við að finna leiðir til að vekja og viðhalda áhuga barnanna.

Aðrir hlutar verkefnisins snerust mestmegnis um fundi barnanna annars vegar og sögu- og ævintýragerð hins vegar par sem petta voru pau atriði sem börnin sóttust mest eftir að eigin frumkvæði. 


\section{Sögugerð, skapandi starf og leikur}

Yfir veturinn náđu sum börnin umtalsverðri færni í að semja sögur. Ein af leiðunum við sögugerð var að nota ipad-spjaldtölvu og forrit eins og Showme (Learnbat.Inc., án árs) og Story creator (Alligator Apps, án árs), en eins og gerðist ítrekað í gegnum vinnuna alla fleytti hugkvæmni kennara og færni verkefninu inn á óvæntar brautir. Dregnar voru fram ritvélar og á pær rituðu kennarar sögur barnanna. Ritvélarnar slógu í gegn, bæði fengu börnin hvert út af fyrir sig mikla athygli við vinnuna við ritvélarnar og sóttust eftir að fá að segja sögurnar sínar en einnig sáu pau stafina birtast strax og höfðu orð á bví að bað væri gott að fá sögurnar iafnóðum. Siá má dæmi

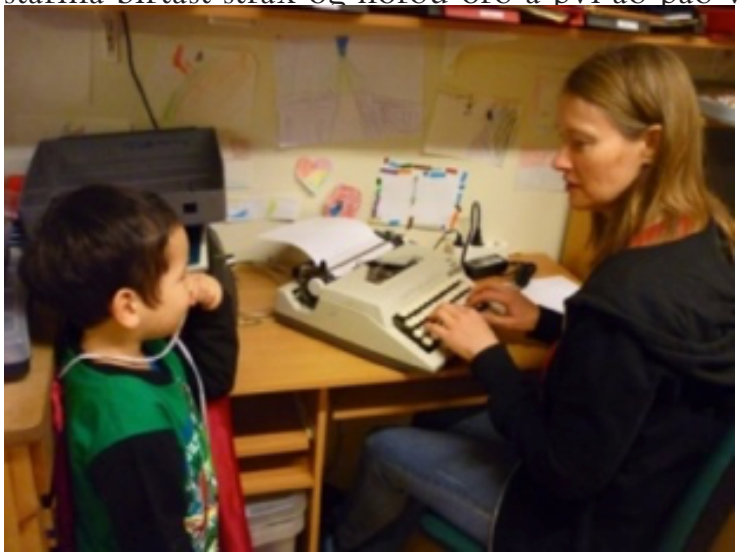

Mynd 3. Saga barns skrádá ritvél

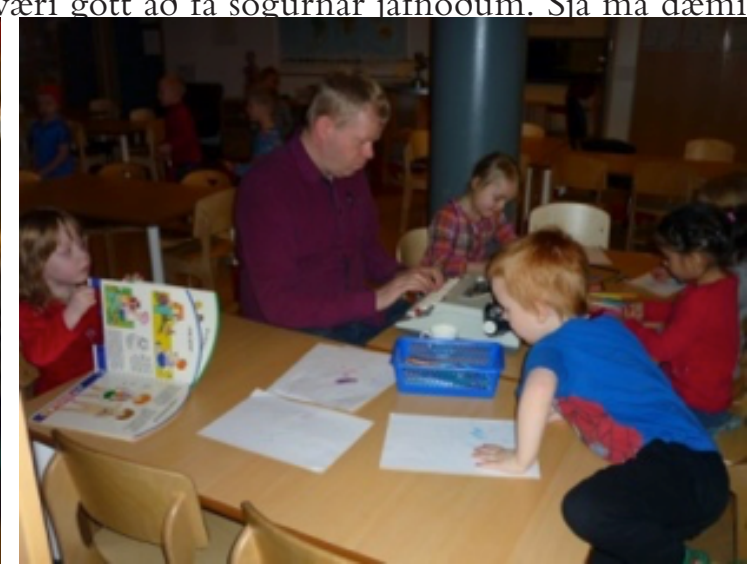

Mynd 4. Barn semur sögu með aðstoð kennara í dagsins önn

um slíka vinnu á Mynd 3 og Mynd 4. Undir lok verkefnisins voru dæmi um ríflega 200 orða sögur með péttu innihaldi, pó sögurnar væru af öllum lengdum og gerðum og flestar 50-60 orð.

Verkefnið hvatti börnin til að skapa og leggja sig fram. Dæmi um petta er stúlka sem endursagði söguna um Rauðhettu fyrir kennara og teiknaði mynd máli sínu til stuðnings. Á fimmtán mínútum teiknaði hún fjórar myndir af ömmunni og í hvert sinn varð myndin ítarlegri og vandaðri. Degar á verkefnið leið sáust dæmi um árangur af umræðu um kynhlutverk í teikningum barnanna. Dæmi var um að drengur lýsti mun á sér og stúlku með pví að teikna strákahjarta fremur en að nota liti, föt eða viðfangsefni til að greina sig frá stúlku. Annað dæmi var pegar stúlka teiknaði pabba sinn í prinsessukjól í albleikri mynd. Ekki er hægt að fullyrða að slík dæmi hafi ekki fundist áður en verkefnið fór af stað en pau voru að minnsta kosti fátíð.

Vettvangsathuganir og skráningar við upphaf verkefnisins sýndu að pegar börnin léku sér í hlutverkaleik léku drengir sína leiki og stúlkurnar sína. ó að hóparnir væru að leik í sama rými voru leikirnir aðskildir og blönduðust ekki að öðru leyti en pví að börnin áttu samskipti ef annar leikurinn fór inn á svæði hins. Í upptökum í janúar má síðan sjá að drengur sóttist eftir hlutverki í leik stúlkna og fékk að vera með peim á sínum forsendum. Рað mætti túlka sem svo að skilin á milli leiks drengja og stúlkna hafi ekki verið eins skýr og áður, en í raun er ekki er hægt að fullyrða um pað af svo takmörkuðu magni upplýsinga. Hins vegar var alveg ljóst að pað var erfiðara fyrir drengi að fara í öll hlutverk, sérstaklega stúlkna eða kvenna. Einn kennarinn sagði:

Verkefnið hafði áhrif á hlutverkaleik barna og í október mátti sjá stelpurnar leika úlfinn og strákarnir fóru að leika Rauðhettu sem kom gleðilega á óvart pví pað hafði sýnt sig að drengirnir áttu erfiðara með að fara í ,stelpuhlutverk“ en stúlkurnar að fara í „strákahlutverk".

Ævintýrin skiluðu sér inn í hlutverkaleik barnanna og ærslaleiki eins og sjá má á Mynd 6. Sögurnar úti voru skoðaðar jafnt og pétt allan veturinn og höfðu greinanleg áhrif á hlutverkaleiki barnanna úti. Börnin fléttuðu sögupersónurnar á myndunum inn í aðra leiki, t.d. sjóræningjaleik eða batmanleiki, og hið sama gerðu pau inni (sjá Mynd 5). Úr skráningu kennara á vinnunni við Rauðhettu má sjá eftirfarandi dæmi um pað hvað reyndist börnunum erfitt í hlutverkaleiknum: 
Við förum út með skott og rauðar húfur (2 derhúfur og 1 rauða hettu). Derhúfurnar urðu strax að pylsuhúfum hjá mönnum sem seldu pylsur. Hettan og skottin voru notuð í Rauðhettuleikrit.Við gerðum tvær tilraunir til að fara í gegnum leikritið. Bæði skiptin enduðu pegar úlfurinn var búinn að gleypa Rauðhettu. Börnin komust ekki áfram prátt fyrir töluverða aðstoð, breytta hlutverkaskipan og að eitthvað af börnunum skiptist út. Dað virtist vera of flókið að leika persónu sem var að leika aðra persónu en að auki átti Rauðhetta erfitt með að spyrja úlfinn sem átti að vera að leika ömmu. Eftir pað varð til úlfaleikur. Börn og kennarar voru úlfar til skiptis og eltu eða reyndu að komast undan og fela sig. Pau sem voru hræddust í upphafi og vildu hvergi vera nálægt voru farin að hlaupa með að lokum, sérstaklega ef barn var úlfurinn.

Áhrif verkefnisins á börnin voru margvísleg. Dau æfðust í að tjá sig og segja skoðanir sínar, sýndu mörg hver framfarir í skapandi páttum, s.s. teikningu, og urðu víðsýnni og gagnrýnni í samræð-

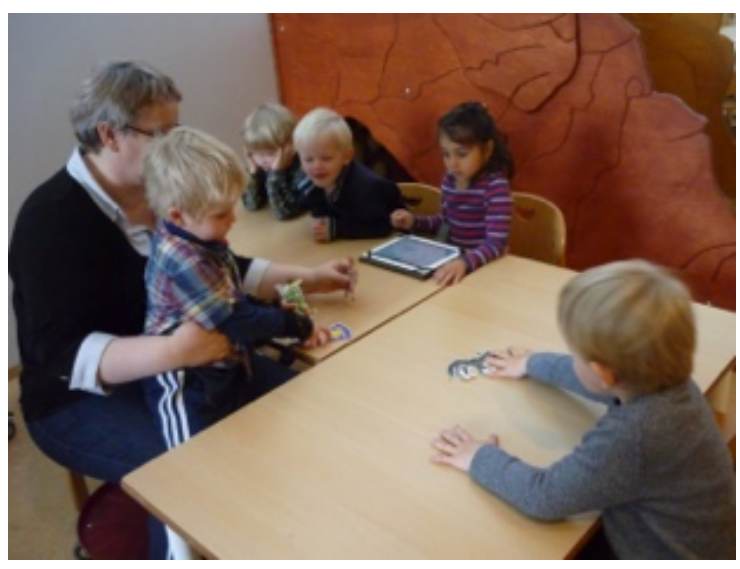

Mynd 5. Sögugerði með ipad og dýramyndum

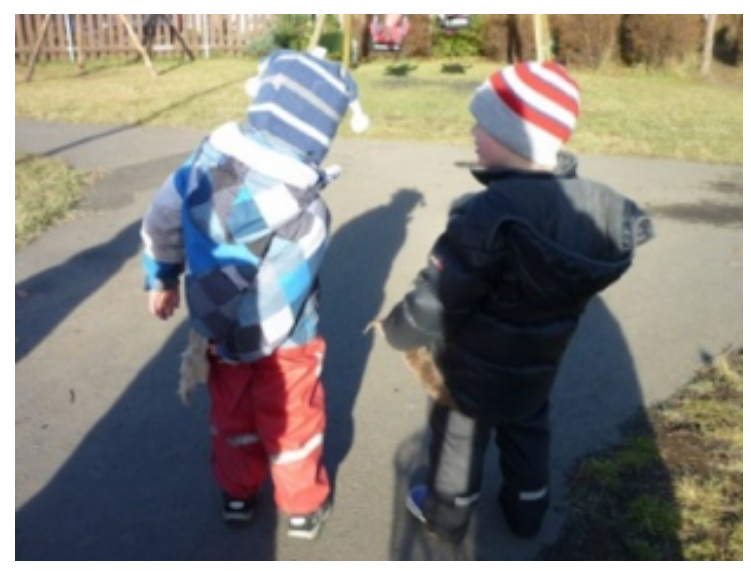

Mynd 6. Úlfaleikur úti við par sem búningurinn er gærubútur

um og leik. Að pví sögðu eru dæmin um hefðbundin kynhlutverk, bæði í teikningu, sögum og umræðum, fleiri en hin.

\section{Fundir barna}

Börnum var reglulega boðið á fundi til að ræða jafnréttismálefni og voru viðfangsefni fundanna sótt í dægurmenninguna; ljósmyndir voru teknar í verslunum, auglýsingar í fréttamiðlum voru notaðar en einnig var stuðst við töluvert af heimagerðu efni (sjá Mynd 7). Börnin sóttust eftir аð funda og höfðu frumkvæði að pví ekki síður en kennarar, og alltaf var útgangspunkturinn sá að pátttaka í fundum væri val barnanna. Hins vegar voru tækifæri sem gáfust dagsdaglega einnig notuð óspart til að ræða við börnin, ein sér eða fleiri saman, og pannig voru öll börnin á deildinni virkir pátttakendur í verkefninu pó sum hefou minni áhuga á fundunum en önnur (sjá Mynd 8).

Degar farið var af stað með umræður með börnunum voru fyrstu viðbrögð peirra gjarnan að svara með pví að segja „ég veit pað ekki“ eða „af pví bara“. Hvort heldur sem börnin voru pannig að komast undan pví að svara ítarlegar eða pau voru óvön að fjalla um flókin málefni var ljóst að mikil pörf var á að æfa tjáningu peirra og samræðuhæfni. Degar á leið náðist töluverður árangur og börnin tóku pátt í umræðum, skiptust á skoðunum og veltu málefnum fyrir sér. Degar hlé varð á vinnunni í kringum jólin mátti greina bakslag á pessu sviði sem sýndi mikilvægi pess að börnin fengju skipulögð og markviss tækifæri til að tjá sig og koma skoðunum á framfæri jafnt og pétt í gegnum alla skólagöngu sína. 


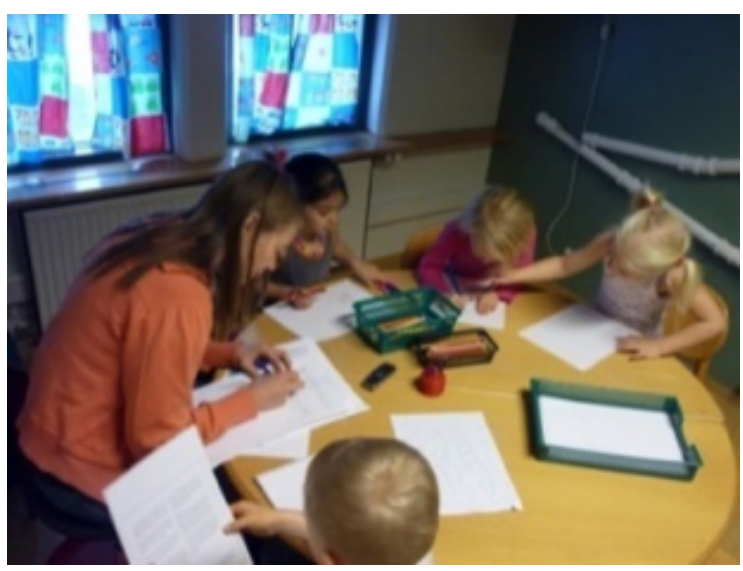

Mynd 7. Kennarar og börn funda og teikna niðurstöðuna

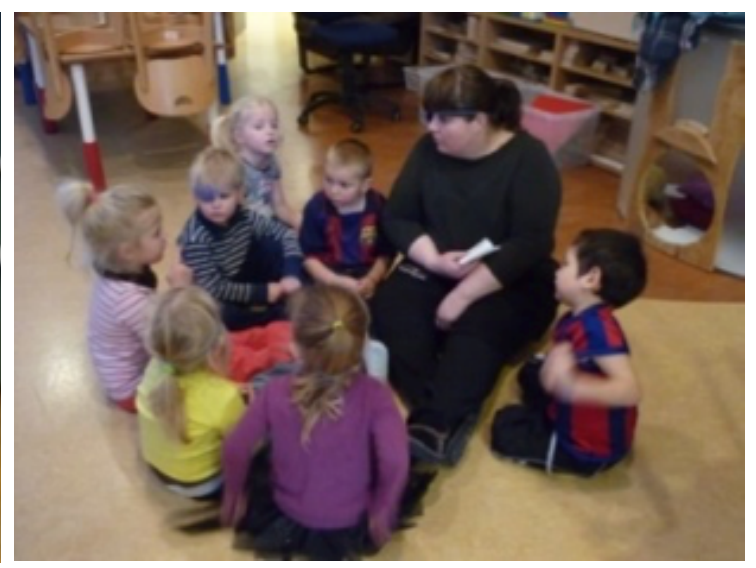

Mynd 8. Kennarar og börn funda og ræða kynhlutverk

Framan af áttu börnin stundum erfitt með að lýsa pví sem pau vildu segja með orðum og gripu pá stundum til teikninga og létu pær lýsa pví sem pau vildu segja. Í gegnum verkefnið allt höfðu börnin gjarnan aðgang að blöðum og litum pegar umræður fóru fram en pó ekki alltaf. Miklar framfarir mátti greina á milli funda við upphaf verkefnisins og í febrúar, eins og sjá mátti af myndum drengs sem í október á erfitt með að orða pað sem mamma gerir í vinnunni og teiknar ómerkingarbært riss til að sýna ritun. Í febrúar teiknar sami drengur mynd af mömmu með smáatriðum og segir „Mamma á að vera í friði með hurðinni. Hún situr við borð og skrifar. Pabbi er að pykjast vinna svo mikið með tvær tölvur.“ Á seinni teikningunni var mamman í aðalhlutverki og drengurinn notaði orð til að lýsa pví sem hún gerði í vinnunni.

Reynslan af umræðufundum barnanna og rýniviðtölum sýndi að pað var afar stutt á milli raunveruleikans og leiks og ímyndunarafls hjá börnunum og stundum komu svörin hinum fullorðna á óvart, eins og petta dæmi úr skráningu sýnir:

Kennari: Hvað viltu vinna við pegar pú verður stór?

Drengur 1: Nei! [ákveðið].

Stúlka: Mér finnst ekki skemmtilegt að vinna, pabbi [hlé] vinna er rosa lengi [hlé] pegar pabbi [hlé] pá parf amma að sækja mig.

Drengur 1 : Mig langar ekki að vinna í neinni vinnu. Nei, mig langar bara að vera alltaf, vera alltaf heima, nú bara horfa á sjónvarið [hlegið].

Drengur 2: Horfa bara á sjónvarpið? [1́ spurnartón].

Stúlka: Bara að horfa á sjónvarpið [hik] ég vil líka bara horfa á sjónvarpið heima.

Drengur 1: Баð er ekki leiðinlegt! [með sannfæringu].

Börnin gátu haldið athygli býsna lengi, sérstaklega ef pau höfðu eitthvað í höndunum, svo sem ef pau fengu að teikna á meðan pau spjölluðu, en svo gátu pau tapað athyglinni afar hratt ef pau misstu áhugann. Sumir fundir og viðtöl tóku skamma stund en önnur teygðust í 30-45 mínútur sem er langur tími fyrir fjögurra ára börn að halda athygli. Í samtölum svöruðu börnin út frá eigin reynslu eða hugmyndum og sýndu ekki mikla pekkingu út fyrir eigin reynsluheim. Degar pau fengu að teikna töluðu pau meira og ef pau fengu myndir til að skoða hjálpaði pað til við að halda einbeitingu við umræðuefni.

Að hausti voru börnin nokkuð staðföst í peim skoðunum sínum að til væru litir, leikföng og hlutverk fyrir börn tengd kyni. Degar á verkefnið leið tjáđu börnin hugmyndir sínar á fjölbreyttari hátt. Dæmi um pað er pegar einn drengjanna teiknaði mynd af „einhverju sem er bara fyrir 
drengi“. Hann hugsaði sig lengi um og teiknaði svo mynd og sagði „,petta er strákaheili“. Dað er kannski of djúpt 1 árinni tekið að segja að honum hafi ekki dottið neitt annað í hug sem greindi á milli drengja og stúlkna en pað fyrsta sem kom í huga hans voru ekki eiginleikar, störf eða geta tengd kyni, sem er viss árangur. Í einni skráningunni voru börnin í Búkolluleik með fólk og dýr og voru að endursegja söguna saman:

Stúlka: Detta er stelpa.

Kennari: Af hverju?

Stúlka: Hún er með sóp.

Drengur: Nei, betta er strákur.

Kennari: Nú, af hverju?

Drengur: Af pví hann er með sóp [svo bendir hann á fléttuna á persónunni og segir] strákar mega vera með svona.

Annað dæmi má taka af stúlkunum sem tóku pátt í umræðu um dreka og voru sannfærðar um að prinsessur gætu ekki drepið dreka en sjálfar réðu pær alveg við verkefni af pví taginu. Petta var töluverð framför frá hugmyndum peirra að hausti, pegar pað kom engan veginn til greina að stúlkur pyrftu ekki prins í slíkt verkefni. Fleiri dæmi má nefna sem sýna að börnin sáu hlutverk sín í víðara samhengi. Drengur teiknaði mynd og sagði „Ég ætla að verða eins og pabbi pegar ég verð stór, elda mat, pvo og skipta á bleyju," og stúlka teiknaði mynd af pabba sínum í prinsessubúningi, fagurbleikum. Allt eru petta dæmi um myndir og tjáningu pvert á hefðbundnar hugmyndir um kynhlutverk, árangur sem beinlínis má rekja til verkefnisins. Slík dæmi voru fáséð áður en verkefnið fór af stað og fundust ekki hjá samanburðarhópnum. Hér verður pó að taka fram að ekki er hægt að sverja fyrir möguleg áhrif pess hvernig kennarar spurðu spurninganna í fyrri rýnihópunum par sem pær voru takmarkaðar við staðalmyndir og gátu í sjálfu sér haft áhrif á svörin á meðan seinni hópurinn fékk ítrekuð tækifæri til umræðu um sama efni. Hins vegar sýndu börnin sem tóku pátt í verkefninu aukna færni í lok vetrar, bæði í tjáningu og umræðu um málefni

\section{Starfsaðferðir kennara og viðhorf}

Við mat á framgangi verkefnisins í janúar kom fram að kennurum pótti umræðan pá pegar hafa skilað greinanlegum árangri; börnin voru færari í að ræða hugmyndir, skoðanir og viðhorf en einnig höfðu pau eflst í að standa á skoðunum sínum. Verkefnið hafði einnig haft áhrifá kennarana. Deir töldu pað hafa gefið sér tækifæri til að líta í eigin barm og íhuga bæði starfsaðferðir sínar og viðhorf.

Við lok verkefnisins voru kennarar sammála um að peir hefðu lært margt um jafnréttisuppeldi og jafnréttiskennslu. Áhrif pessa mætti greina bæði á vinnubrögðum og bví að peir hefðu orðið meðvitaðri um pætti sem snúa að jafnrétti, m.a. hvernig peir ræddu við börnin, svöruðu spurningum og legðu fyrir verkefni (sjá Mynd 9 og Mynd 10). Kennarar töldu sig gagnrýnni á eigin störf og meira vakandi fyrir pví hvernig mætti vinna að jafnrétti í leikskóla. Deir töldu að góð reynsla hefði komist á vinnubrögð og aðferðir og sú reynsla yrði peim til gagns um komandi ár. Deim pótti mikilvægt að fjölbreyttum aðferðum var beitt í verkefninu og töldu að sampættingin skipti máli pví pannig væri alltaf af nægum hugmyndum að taka og hægt að flétta jafnréttisumræðu inn í starf og leik sem víðast í leikskólastarfinu. Sú nálgun auðveldaði kennurunum einnig að taka pátt í sumum hlutum verkefnisins án pess að purfa að sinna peim öllum. Kennararnir töldu einnig að fjölbreytt nálgun viðhéldi áhuga, bæði kennara og barna, og gerði öllum auðveldara um vik að finna nýja fleti að vinna að. 


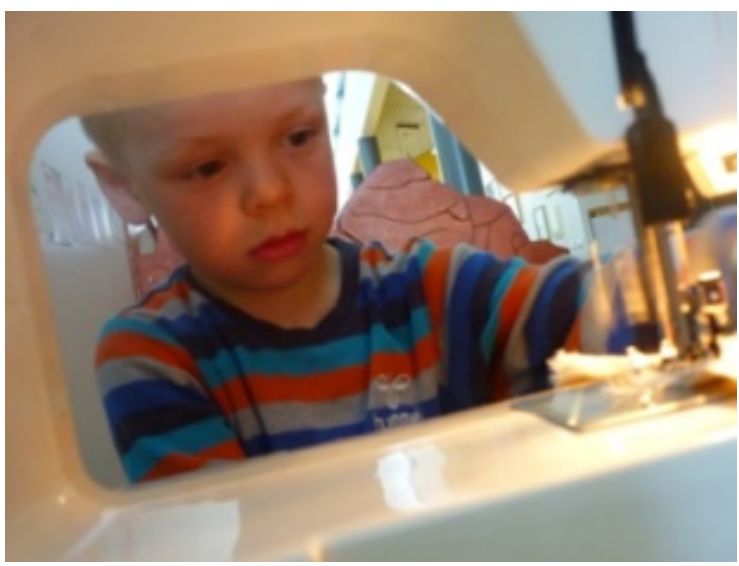

Mynd 9. Drengur saumar föt á tröll

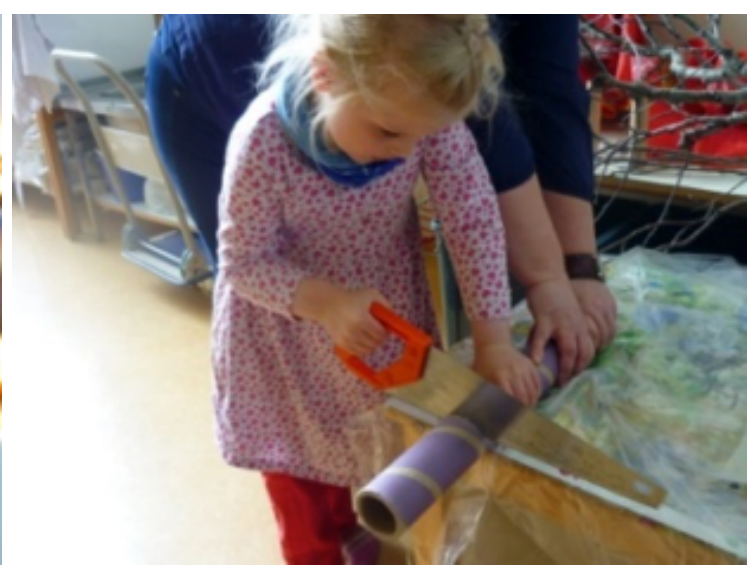

Mynd 10. Stúlka sagar efni í búkinn á trölli

\section{Mat foreldra á jafnréttisverkefninu}

Að hausti leist foreldrum almennt vel á verkefnið og höfðu trú á að vinna með jafnrétti gæti skilað árangri. Deir sögðust hafa fengið næga kynningu á verkefninu og töldu fréttabréf vera heppilega leið til að fá upplýsingar, en einnig mætti nota upplýsingatöflu í forstofu og á heimasíðu deildarinnar, og almennt væri nóg að fá upplýsingar einu til tvisvar sinnum í mánuði. Dessi niðurstaða réð miklu um pað hvernig kynningum var háttað í kjölfarið. Stór hluti foreldra vildi fá fræðslu um jafnréttismál og margir vildu aðgengi að lesefni um jafnréttisuppeldi. Við hvoru tveggja var brugðist; haldið var málping um jafnréttisuppeldi og stofnað örbókasafn í leikskólanum. Foreldrar voru spurðir hvaða pættir í verkefninu peim pættu mikilvægir og flestir nefndu sögugerð og vinnu með ævintýri og skapandi starf, í pessari röð eftir mikilvægi. Leikinn settu foreldrar í fjórða sæti og vinnu með kynhlutverk í pað fimmta, par næst komu samræður og að lokum jafnrétti. Niðurstaðan sýnir að foreldrar voru ánægðir með nálgunina í gegnum ævintýrin og hlynntir áherslum á skapandi starf. Forgangsröðun foreldranna gefur síðan forvitnilegar vísbendingar sem áhugavert væri að skoða nánar síðar.

Fjórtán foreldrar tóku pátt í mati að vori, við lok verkefnisins. Langflestir foreldrarnir sögðust mest hafa orðið varir við sögugerðina, pá hefði skapandi starf verið sýnilegt og sjá mætti áhrif verkefnisins á leik barnanna og greina jafnréttisáherslur. Minnst töldu foreldrar sig sjá merki um ævintýrin, pátt sem peir töldu næstmikilvægasta pátt verkefnisins að hausti. Mögulega er ástæðan sú að megináhersla á ævintýrin var í upphafi verkefnisins og pau ætluð til að opna leiðir að umræðum og öðrum páttum jafnréttiskennslunnar. Samkvæmt áætlun áttu fundir og umræður að taka við seinni hluta vetrar og varð sú raunin. Foreldrar nefndu að börnin ræddu heima fyrir um kynhlutverk, t.d. að karl gæti verið Rauðhetta eða klætt sig í kjól ef hann vildi. Eitt foreldri greindi áhrif verkefnisins á umræðu heima fyrir um mismunandi hlutverk, svo sem hver gerði hvað, en einnig á umræðu um getu hvers og eins. Annað foreldri taldi barn sitt sýna aukinn áhuga á að hlusta á sögur og pað hefði verið greinilegt að börnunum hefði pótt verkefnið skemmtilegt. Niðurstaðan er sú að foreldrar höfðu almennt áhuga á fræðslu og umræðu um jafnréttisuppeldi og áhugi peirra og stuðningur var m.a. greinanlegur á góðri mætingu á fundi og í vinnusmiðju, á pátttöku peirra á fésbók og á almennum samræðum frá degi til dags. Málping í mars var einnig vel sótt og pátttaka í umræðum gagnleg og gagnrýnin. 


\section{Rannsóknarspurningar og markmið verkefnisins}

Rannsóknarspurningar voru prjár:

- Hvernig geta kennarar próað leiðir til markvissrar jafnréttis- og kynjaumræðu leikskólabarna?

- Hvernig má vinna með ævintýri sem lið í jafnréttiskennslu?

- Hvernig má efla pátttöku og framlag barna?

Svör við rannsóknarspurningunum eru pau að fjögurra ára börn hafa hugmyndir um kynhlutverk og jafnrétti út frá hefðbundnum staðalmyndum en með skipulagðri og stöðugri umræðu má vinna með pær. Kennarar telja sig einnig hafa gagn af markvissri fræðslu um kynjafræði og skólastarf.

Markmið verkefnisins voru eftirfarandi:

- $\quad$ Að vinna með og efla jafnréttisvitund leikskólabarna.

- $\quad$ Að efla vitneskju kennara um leiðir og árangur af markvissri jafnréttis- og kynjafræðiumræðu.

- $\quad$ Að leita árangursríkra leiða til að vinna með jafnrétti og kynjafræði í leikskóla.

Unnið var markvisst og eftir fjölbreyttum leiðum að pví að efla jafnréttisvitund barnanna.

Árangur var nokkur, ekki síst í pví að styðja börnin til gagnrýni á staðhæfingar og hugmyndir. Kennarar á deildinni telja sig vera meðvitaðri um jafnrétti og betur vakandi fyrir pví sem hægt sé að vinna með. Verkefnið og kennsluleiðbeiningarnar verður hægt að nálgast á vef og pví er mögulegt að aðrir geti nýtt sér petta efni að hluta til eða sem heild. Sögugerð og umræður eru aðferðir sem munu lifa áfram og verða fastur hluti af starfi deildarinnar. Kennarar eru sammála um að pannig má vinna að jafnrétti og lýðræði og ná árangri á mörgum sviðum.

\section{Umræða}

Rétt er að minna á að pátttaka barnanna í einstökum hlutum verkefnisins var mismikil enda gjarnan valkvæð. Af pví leiddi að sum börn náđu meiri árangri en önnur í ýmsum páttum pó áhugasvið og proski hafi án efa einnig haft áhrif. Kennarar og verkefnisstjóri eru sammála um að раð mikilvægasta við verkefnið sé að раð skapaði umræðugrundvöll. Framfarir barnanna í samræðum urðu umtalsverðar og pað gefur peim aukna möguleika til að koma skoðunum sínum á framfæri. Deir sem að verkefninu unnu eru einnig sammála um mikilvægi pess að hafa haft sögurnar sem upphafspunkt pví pær komu bæði kennurunum og börnunum af stað inn í verkefnið. Раð gaf einnig góða raun að nota dægurmenninguna sem útgangspunkt á fundum og verkefni henni tengd gerðu vinnuna markvissari. Afpreyingarefni, auglýsingar, föt og litir voru umræðuefni, svo dæmi séu tekin, og allt eru petta áhrifapættir í mótun kyngervis, eins og fram hefur komið í fjölmörgum rannsóknum (Jackson, 2007; Jones og Dindia, 2004; Pórdís Pórðardóttir, 2012; Änggård, 2005). Gagnrýnin umræða er leið til að gefa börnum aukið vald yfir eigin lífi og umræða um pað sem stendur peim næst er leiðin sem líklegust er til að skila árangri (Blaise, 2005). Ein af peim niðurstöðum sem komu hvað mest á óvart var að færni barnanna til gagnrýninnar umræðu virtist minnka pegar hlé var gert á fundum. Í pví felast mikilvægar upplýsingar sem sýna að jafnréttisfræðsla parf að vera stöðug og að afmörkuð verkefni eins og petta duga ekki til lengri tíma litið. Ingólfur Ásgeir Jóhannesson (2011) hefur einmitt bent á mikilvægi pess að jafnréttisfræðsla í skólum sé markviss og samfelld.

Kennarar próuðu með sér fagleg vinnubrögð í gegnum verkefnið og juku færni sína á mörgum peim sviðum sem próunarverkefnið tók til. Peir fundu fjölbreyttar leiðir til að kveikja áhuga barnanna og viðhalda honum í gegnum ferlið allt og má par nefna sem dæmi leikritið sem peir 
settu á svið og skipti sköpum í að koma verkefninu af stað eftir hnökra í byrjun. Peir urðu einnig færari í að greina og grípa tækifæri til að ræða og vinna með jafnrétti með börnunum en jafnrétti er einn af grunnpáttum menntunar (Aðalnámskrá leikskóla, 2011) og rannsóknir hafa sýnt að skortur er á jafnréttisfræðslu í skólastarfi (sjá t.d. Eygló Árnadóttur, 2009; Porgerði Einarsdóttur og Ingólf Ásgeir Jóhannesson, 2011).

Börnin höfðu staðalmyndir af hlutverkum fólks eftir kyni, sem er niðurstaða sem fleiri rannsakendur hafa komist að (Blaise, 2005; Jackson, 2007; Patterson og Bigler, 2006). Drengirnir áttu erfiðara með að fara yfir línuna á milli kynhlutverka og virtust hafa skýra mynd af pví hvað peir töldu viðeigandi fyrir pá sem drengi og hvað ekki. Í pessu samhengi má minna á rannsókn Bauer (1993) par sem drengir svo ungir sem tveggja ára gamlir samsömuðu sig staðalmyndum. Раð gerðu peir bæði fyrr og sterkar en stúlkur. Vandinn pessu samfara er pegar kyngervið takmarkar möguleika barna, sem virðist vera raunin og var ein af niðurstöðunum í rannsókn Guðrúnar Öldu Harðardóttur (2014). Rannsóknir hafa einnig sýnt að svigrúm karla til að ganga pvert á staðalmyndir er minna en kvenna (sjá t.d. Kauppinen-Toropainen og Lammi 1993; King 1998; Williams og Villemez, 1993) og ljóst er að drengir upplifa sambærilegan prýsting, en pað er staðreynd sem er að mörgu leyti áhyggjuefni fyrir bæði kynin. Fyrst og fremst er pað alvarlegt mál ef börn hafa frá unga aldri hugmyndir um að veruheimur kvenna sé minna virði en karla (Pórdís Pórðardóttir, 2012), en ekki síour má velta fyrir sér langtímaáhrifum af pví að börn upplifi kynjatengdar skorður við val á viðfangsefnum, eiginleikum og tækifærum.

Umræðufundir æfou börnin í að tala um málefni og fljótt mátti sjá aukna færni í að svara spurningum og ræða málefni, sem er í samræmi við tilmæli í Aðalnámskrá leikskóla (2011), en par segir að skólar purfi að skapa börnum tækifæri til að ræða og vinna verkefni tengd jafnrétti. Hvort tveggja var gert í próunarverkefninu. Eitt af pví sem kom mest á óvart í niðurstöðunum var að ef gert var hlé á vinnu við fundina tapaðist árangur, jafnvel bó hann ynnist fljótt upp aftur. Petta er mikilvægt atriði og sýnir að jafnréttisfræðsla verður að vera stöðug og markviss, sérstaklega með yngri börnum. Jafnrétti er grunnpáttur í menntun barna (Aðalnámskrá leikskóla, 2011) og fræðimenn á pessu sviði hafa áréttað mikilvægi pess að skólar vinni markvisst og stöðugt að jafnrétti (Eygló Árnadóttir, 2009: Ingólfur Ásgeir Jóhannesson, 2011; Porgerður Einarsdóttir og Ingólfur Ásgeir Jóhannesson, 2011). Til að svo megi vera purfa kennarar fræðslu og í kennarahópnum pyrfti að ræða reglulega um jafnrétti og vinna með pað í starfsmannahópnum. Ekki síst parf að takast á við orðræðuna sem Deutsch (2007) telur ríkjandi við mótun kyngervis. Annað sem parf аð ræða meðal kennara er að staðalmyndir eru áhrifapáttur í starfi íslenskra leikskóla (Anna Elísa Hreiðarsdóttir, 2006; Laufey Axelsdóttir og Gyða Margrét Pétursdóttir, 2014) og með pær parf að vinna. Pví eru jafnréttisverkefni í skólastarfi mikilvæg og pau purfa að snúa jafnt að börnum og kennurum og ættu að vera fastur liður í starfi allra skóla.

\section{Lokaorð}

Meginniðurstaðan er sú að verkefnið Ævintýralegt jafnrétti skilaði peim árangri að börnin urðu gagnrýnni á umhverfi sitt og færari um að ræða um jafnréttistengd málefni, en pau ræddu einnig um lýðræði og mannréttindi enda eru peir pættir nátengdir jafnrétti. Verkefnið vakti vitund kennara um að börn eru mikið til raddlaus í samfélaginu, jafnvel í skólanum sínum, og purfa pví pjálfun og æfingu í að tjá sig og hugsa með gagnrýnum hætti. Pegar börn fá að láta í sér heyra hefur pað jákvæð áhrif á pau sjálf og byggir upp sjálfsmynd peirra. Áhugi foreldra á jafnréttisverkefninu og ákall peirra eftir fræðslu og umræðu er einnig mikilvægur páttur sem full pörf er á að hafa í huga og vinna að í framtídinni.

Undir lok hins formlega próunarverkefnis voru kennarar staðráđnir í að halda áfram að vinna með ævintýri og sögugerð vegna pess hve árangursrík sú leið pótti til að vinna með jafnrétti, lýðræði og skapandi hugsun barnanna. Eitt af pví sem verkefnið kallaði á var vettvangur fyrir foreldra og kennara til að skiptast á skoðunum og ræða um jafnrétti. Dví var búinn til fésbókarhópur sem heitir Jafnrétti í uppeldi og menntun ungra barna. Petta er hópur ætlaður foreldrum 
og kennurum með áhuga á jafnrétti og eru pátttakendur rúmlega 200. Dar fer m.a. fram umræða um og dreifing á áhugaverðu efni. Hópurinn er öllum opinn og enn virkur.

Раð er starfsmönnum á Prymheimi að pakka að verkefnið tókst svo vel sem pað gerði. Deir unnu ötullega að pví að veita verkefninu brautargengi og halda pví vakandi allt skólaárið. Arnar Yngvason deildarstjóri greiddi götu allra hugmynda, hversu skyndilega sem pær komu upp, og sá um tæknivinnuna, m.a. teikningarnar á spjaldtölvurnar. Ólöf Jónasdóttir vann að sögugerð og umræðum með börnunum, ásamt pví að sjá um skráningar. Kristín Elva Magnúsdóttir hélt meðal annars utan um tröllaverkefnið og, síðast en ekki síst, vann Hólmfríður Pórðardóttir ötullega að verkefninu allan tímann, bar á pví meginábyrgð í skólanum og hélt utan um fundi með börnum og aðra pætti af áhuga og ósérhlífni.

\section{Equality and fairytales. Action research in a preschool}

This article describes action research intended to monitor a developmental project on gender equality and fairy tales in a preschool in Akureyri. The project was conducted in the school year 2013-2014. The author took part in the study, as project manager, along with the teachers. The Ministry of Education, Science and Culture sponsored the project through the Venture Fund for Preschools, Primary and upper Secondary Schools.

According to the Icelandic National Curriculum for Preschools, equality is one of the fundamental pillars of education and, as the curriculum states: "critical examination is an important part of equality education, for example because established ideas in the society influence ideas and views and therefore it is critical to teach young children to voice and analyse the circumstances that lead to discrimination of some and privileges for others" (Aðalnámskrá leikskóla, 2011). It is clear that schools are supposed to work on and teach equality but in reality, studies show both those aspects to be lacking (Eygló Árnadóttir, 2009; Dorgerður Einarsdóttir \& Ingólfur Ásgeir Jóhannesson, 2011). One reason could be a shortage of teaching materials, especially in gender equality. Therefore, it is important to work towards equality in schools and it is of particular significance to develop educational material for teachers. The main purpose of the developmental project was to increase teachers' knowledge of gender education and to develop methods in equality and gender teaching, as well as working on, and improving, preschool children's gender awareness, and finding ways to develop equality and gender education in preschools.

The goal of the action research was to empower the teachers as professionals and further their skills to develop their own teaching methods by systematically paying attention to the project and revising it, especially the participation of the children and their contribution. The participants consisted of a classroom of 4 year olds and their teachers.

Data was gathered through photographs, video recordings and audio recordings of meetings and interviews with teachers and pupils, as well as with the control group; recordings were performed by the teachers and the project manager. Children's projects and artwork were also gathered systematically.

During the project teachers worked with their own views and awareness, as well as with the children's views and awareness. The focus was on gender equality, gender issues and stereotypes, and the teachers used fairy tales and story making to en- 
hance gender awareness. The aim was to integrate equality teaching with indoor and outdoor activities and play. The children had opportunities to participate in conversations on gender issues, such as tasks, roles or characteristics based on gender, and talk about discrimination and privileges. Part of this process was to teach the children to practice critical thinking. The plan was to choose well-known fairy tales as it is more likely that the children would have heard them before, and these particular fairy tales were chosen because they were considered to have aspects that suited the project well. For example, none of them included princesses, nor did they end in marriage. They do, however, contain characters of both genders who exhibit both affection and courage.

Data was gathered from various sources throughout the study period, such as notes from teachers' meetings, and group work with children, where the aim was to discuss the children's views on gender, stereotypes and their beliefs about possibilities and opportunities in the context of gender. Furthermore, the data included teachers' diaries and documentation from children's participation as they took part in preschool activities such as play, and creative activities, for example drawing, writing stories or dramatic play. Part of this project was to create teaching materials, to be made accessible online through the website idavollur.is.

The findings show that through this process the teachers became more aware of their views and ideas regarding gender equality, as well as their own teaching methods. It also became clear that it was crucial for the process that the teachers took initiative in the teaching, for instance by taking the opportunity, on a daily basis, to encourage the children and find new ways to draw attention to equality and inequality and to maintain interest and new perspectives. The findings also indicate that children's participation in systematic discussion increased with time but this ability decreased fast if it was not maintained.

Key words: Preschool, gender equality, fairytales, gendering, action research.

\section{Um höfund}

Anna Elísa Hreiðarsdóttir (annaelisa@unak.is) er lektor við kennaradeild Háskólans á Akureyri. Hún brautskráđist frá Fósturskóla Íslands árið 1990 sem fóstra, lauk B.Ed.-gráđu frá Háskólanum á Akureyri árið 2000 og M.Ed.-prófi sex árum síðar frá sama skóla. Anna Elísa starfaði um árabil sem leikskólastjóri, aðstoðarleikskólastjóri og deildarstjóri í leikskóla. Rannsóknir hennar og próunarverkefni snúa meðal annars að foreldrasamstarfi í leikskóla, jafnréttiskennslu yngri barna og starfi með elstu börnum leikskólans.

\section{About the author}

Anna Elísa Hreiðarsdóttir (annaelisa@unak.is) is an assistant professor at the University of Akureyri. She graduated as a kindergarten teacher in 1990, holds a B.Ed. degree in preschool teaching from the University of Akureyri (2000) and an M.Ed. degree from the University of Akureyri (2006). Anna Elísa has worked as a preschool teacher and a head teacher. Her research focuses on partnership with families in preschools, professional work with five-year-old children and gender studies. Anna has worked on several developmental projects in the same areas. 


\section{Heimildir}

Aðalnámskrá leikskóla 2011 /2011.

Alligator Apps. (án árs). Story Creator. http://www.alligatorapps.com/

Andrea Hjálmsdóttir og Póroddur Bjarnason. (2008a). „Egalitarian attitudes towards the division of household labor among adolescents in Iceland“. Sex Roles 59(1-2), 49-60.

Andrea Hjálmsdóttir og Póroddur Bjarnason. (2008b). ,Og seinna börnin segja: Petta er einmitt sú veröld sem ég vil“...? Breytingar á viðhorfum 10. bekkinga til jafnréttismála, 1992-2006. Uppeldi og menntun, 17(2), 74-86.

Anna Elísa Hreiðarsdóttir. (2006). Fólk heldur að við séum fleiri.Viðtalsrannsókn við íslenska karlleikskólakennara (óútgefin meistararitgerð). Háskólinn á Akureyri, Akureyri. Sótt af http://hdl.handle.net/1946/1228

Anna Elísa Hreiðarsdóttir. (2014).Ævintýralegt jafnrétti. Kennsluefni í jafnréttisfræðu í leikskóla. Sótt af https://throunarverkefniogrannsoknir.wordpress.com/2017/04/12/first-blog-post/

Bauer, P. J. (1993). Memory for gender-consistent and gender-inconsistent event sequences by twenty-five-month-old children. Child Development, 64(1), 285-297.

Berglind Rós Magnúsdóttir, Guðrún M. Guðmundsdóttir, Jóna Pálsdóttir, Kristín Ástgeirsdóttir og Kristín Jónsdóttir. (2010). Kynungabók. Reykjavík: Mennta- og menningarmálaráðuneytið. Sótt af https://www.menntamalaraduneyti. is/media/MRN-pdf/kynungabok-vefutgafa.pdf

Blaise. M. (2005). A feminist poststructuralist study of children „doing“ gender in an urban kindergarten classroom. Early Childhood Research Quarterly, 20(1), 85-108.

Blaise, M. og Taylor,A. (2012). Using queer theory to rethink gender equity in early childhood education. Young Children 67(1), 88-96. Sótt af http://search.proquest.com/docview/927664755?pq-origsite=gscholar

Browne, N. (2004). Gender equity in the early years. England: Open University Press.

Butler, J. (2004). Undoing gender. London: Routledge.

Davies, B. (2003). Frogs and snails and feminist tales: Preschool children and gender. New York: Hampton Press.

Deutsch. F. M. (2007, febrúar). Doing gender. Gender \& Society, 21(1), 106-127. Doi:10.1177/0891243206293577

Dockett, S., Jóhanna Einarsdóttir og Perry, B. (2012). Children's decisions about research participation: Opting out. International Journal of Early Years Education, 20(3), 244-256.

Eliot, L. (2009). Pink brain, blue brain. How small differences grow into troublesome gaps - and what we can do about it. New York: Harcourt Publishing Company.

Eygló Árnadóttir. (2009). Ekki benda á mig! Um framkvamd laga um jafnréttisfreðslu í grunnskólum (óútgefin meistararitgerð). Háskóli Íslands, Reykjavík.

Fine, C. (2010). The real science behind sex differences. Delusions of gender. London: Icon Books.

Frost, J., Wortham, S. og Refiel, S. (2008). Play and child development. Upper Saddle River: Pearson.

Guðrún Alda Harðardóttir. (2014). Námstækifæri barna í leikskóla. Tækifæri leikskólabarna til pátttöku og áhrifa á leikskólanám sitt (óútgefið doktorsverkefni). Háskóli Íslands, Reykjavík.

Guðrún Alda Harðardóttir og Gyða Margrét Pétursdóttir. (2014, 6. maí). Gendering in one Icelandic preschool. Nordic Early Childhood Education Research Journal, 7(9), 1-14. Doi.org/10.7577/nbf.681

Hausmann, R.,Tyson, L. D., Bekhouche,Y. og Zahidi, S. (ritstjórar). (2014). The global gender gap report 2013. Genf, Sviss: World Economic Forum. Sótt af http://www3.weforum.org/docs/GGGR14/GGGR_CompleteReport_2014.pdf

Idavollur.is. [án árs]. Leikskólinn Iðavöllur. Sótt af idavöllur.isIngólfur Ásgeir Jóhannesson. (2011, 31. desember). Kynjajafnréttisfræðsla í skólum: Hindranir og tækifæri. Rádstefnurit Netlu-Menntakvika 2011. Sótt af http://netla.hi.is/ menntakvika2011/030.pdf

Jackson, S. (2007). She might not have the right tools... and he does: Children's sense-making of gender, work and abilities in early school readers. Gender and Education, 19(1) 61-77. Doi:10.1080/09540250601087769

Jones, S. og Dindia, K. (2004). A meta-analytic perspective on sex equity in the classroom. Review of Educational Research, 74(4), 443-471.

Jóhanna Einarsdóttir. (2009). Starfendarannsóknir. Reykjavík: RannUng. Sótt af http://menntavisindastofnun.hi.is/sites/ menntavisindastofnun.hi.is/files/rannung/umstarfendarannsoknir.pdf

Katrín Friðriksdóttir og Sigrún Aðalbjarnardóttir. (2002). Ég ákvað að verða kennari pegar ég varð sjö ára. Lífssaga kennara og uppeldissýn. Uppeldi og menntun, 11(1), 121-145.

Kauppinen-Toropainen, K. og Lammi, J. (1993). Men in female-dominated occupations. A cross-cultural comparison. Í Christine L. Williams, (ritstjóri). Doing ,women's work“: Men in nontraditional occupations. Research on men and masculinities (bls. 91-112). Newbury Park, Kaliforníu: Sage.

King,J. R. (1998). Uncommon caring. Learning from men who teach young children. New York og London:Teachers College. 
Laufey Axelsdóttir og Gyða Margrét Pétursdóttir. (2014, 20. ágúst). Kynjaðar væntingar til kvenna og karla í tveimur leikskólum. Netla - veftímarit um uppeldi og menntun. Sótt af http://netla.hi.is/greinar/2014/ryn/002.pdf

Learnbat.Inc. (án árs). ShowMe. http://www.showme.com/

Lucas-Stannard, P. (2012). Gender neutral parenting. Raising kids with the freedom to be themselves. [e-bók, án staðsetningar]: Verity.

Lög um grunnskóla nr. 2008/91.

Lög um jafna stöðu og jafnan rétt kvenna og karla nr. 96/2000.

Lög um leikskóla nr. 2008/90.

Lög um samning Sameinuðu pjóðanna um réttindi barnsins nr. 19/2013.

Maríanna Clara Lútersdóttir. (2012). Spegill, spegill, herm pú mér... Birtingarmyndir kvenna í hreyfimyndum Disney og Pixar (óútgefin meistararitgerð). Háskóli Íslands, Reykjavík.

McNiff, J. (2013). Action research for professional development. Principles and practice (3. útgáfa). London og New York: Routledge.

Montgomery, H. (2009). An Introduction to childhood. Anthropological perspectives on children's lives. West Sussex: Wiley-Blackwell.

Paechter, C. (2007). Being boys, being girls: Learning masculinities and feminities. New York: Open Press.

Palaiologou, I. (2016). Child observation. A guide for students of early childhood. London: Sage.

Patterson, M. M. og Bigler, R. S. (2006). Preschool children's attention to environmental messages about groups: Social categorization and the origins of intergroup bias. Child Development, 77(4), 847-860. Doi:10.1111/j.14678624.2006.00906.x

Pruit, J. C. (2015). Preschool teachers and the discourse of suspicion. Journal of Contemporary Ethnography 44(4), 510-534. Doi:10.1177/0891241614545882

Ridgeway, C. L. og Correll, S. J. (2004). "Unpacking the gender system“. Gender \& Society, 18(4), 510-531.

Spade,J. C. ogValentine, C. G. (2008). The kaleidoscope of gender. Prisms, patterns and possibilities (2. útgáfa). Los Angeles: Sage.

Sprotasjóður.is. Lokaskýrslur verkefna úthlutunarárið 2013-2014. Sótt af http://www.sprotasjodur.is/is/um-sprotasjod/ lokaskyrslur/2013-2014

Verzlunarmannafélag Reykjavíkur. (2015). Launakönnun 2015. Reykjavík: Höfundur. Sótt af http://vr.is/kannanir/ launakonnun-2015/

West, C. og Zimmerman, D. H. (1987). "Doing gender", Gender \& Society, 1(2), 125-151.

Williams, C L. ogVillemez, W. J. (1993). Seekers and finders. Male entry and exit in female-dominated jobs. Í C. L. Williams (ritstjóri). Doing ,women's work“: Men in nontraditional occupations. Research on men and masculinities (bls. 64-90). Newbury Park, Kaliforníu: Sage.

Winswold, A. og Solberg, A. (2010). Leiðir til að virkja börn til pátttöku - nokkur dæmi. Norrant rit í tilefni 20 ára afmalis Barnasáttmála SP. (TemaNord2010/547). Norræna Ráðherranefndin: Kaupmannahöfn.

Porbjörg Helga Vigfúsdóttir, Óttar Proppé, Nanna K. Christiansen, Sigulaug Hrund Svavarsdóttir, Jón Páll Haraldsson, ... Bergsteinn Pór Jónsson. (2011). Skýrsla starfshóps um námsárangur drengja. Reykjavík: Skóla- og frístundasvið Reykjavíkurborgar. Sótt af http://reykjavik.is/sites/default/files/ymis_skjol/skjol_utgefid_efni/starfshopurumnamsvandadrengja_2011.pdf

Dorgerður Einarsdóttir og Ingólfur Ásgeir Jóhannesson. (2011, 31. desember). Kynjajafnréttisfræðsla í skólum. Hindranir og tækifæri. Rádstefnurit Netlu - Menntakvika 2011. Sótt af http://netla.hi.is/menntakvika2011/030.pdf

Dórdís Dórðardóttir. (2012). Menningarlæsi. Hlutverk barnaefnis í uppeldi og menntun telpna og drengja í tveimur leikskólum (óutgefið doktorsverkefni). Háskóli Íslands, Reykjavík.

Pórdís Pórðardóttir. (2015, 31. ágúst). Virðingarsess leikskólabarna. Dekking á barnaefni, kynjun og lagskipting í tveimur leikskólum. Netla - Veftímarit um uppeldi og menntun. Sótt af https://skemman.is/bitstream/1946/23364/1/\%C3\%9E\%C3\%B3rd\%C3\%ADs\%20\%C3\%9E\%C3\%B3r\%C3\%B0ard\%C3\%B3ttir.pdf

Änggård, E. (2005). Barbie princesses and dinosaur dragons: Narration as a way of doing gender. Gender and Education, 17(5), 539-553. Doi:10.1080/09540250500192777

Anna Elísa Hreiðarsdóttir. (2018).

Ævintýralegt jafnrétti. Starfendarannsókn í leikskóla.

Netla - Veftímarit um uppeldi og menntun. Menntavísindasvið Háskóla Íslands.

Sótt af http://netla.hi.is/greinar/2018/ryn/04

DOI: https://doi.org/10.24270/netla.2018.4 